\title{
Bactericidal effect of S-nitrosothiols against clinical isolates from keratitis
}

This article was published in the following Dove Press journal:

Clinical Ophthalmology

19 November 2012

Number of times this article has been viewed

\author{
Angelino Julio Cariello' \\ Paulo José Martins Bispo² \\ Gabriela Freitas Pereira \\ de Souza ${ }^{3}$ \\ Antonio Carlos Campos \\ Pignatari $^{2}$ \\ Marcelo Ganzarolli \\ de Oliveira ${ }^{3}$ \\ Ana Luisa Hofling-Lima' \\ 'Department of Ophthalmology, \\ ${ }^{2}$ Division of Infectious Diseases, \\ Federal University of São Paulo, \\ ${ }^{3}$ Institute of Chemistry, University \\ of Campinas, Campinas, São Paulo, \\ Brazil
}

Background: The purpose of this study was to evaluate the antimicrobial activity of two nitric oxide donors, ie, S-nitrosoglutathione (GSNO) and S-nitroso-N-acetylcysteine (SNAC), against clinical isolates from patients with infectious keratitis.

Methods: Reference broth microdilution assays were performed to determine the minimum inhibitory and bactericidal concentrations for GSNO and SNAC against four American Type Culture Collection strains and 52 clinical isolates from patients with infectious keratitis as follows: 14 (26.9\%) Pseudomonas species; 13 (25.0\%) coagulase-negative Staphylococci; 10 (19.2\%) Staphylococcus aureus; nine (17.3\%) Serratia marcescens; and six (11.5\%) Enterobacter aerogenes. Sterility control and bacterial growth control were also performed.

Results: SNAC showed lower minimum inhibitory and bactericidal concentrations than GSNO for all clinical isolates from patients with infectious keratitis. For Gram-positive bacteria, mean minimum inhibitory and bactericidal concentrations were $2.1 \pm 1.3$ and $8.6 \pm 3.8 \mathrm{mM}$ for SNAC and $4.6 \pm 3.2$ and $21.5 \pm 12.5 \mathrm{mM}$ for GSNO $(P<0.01)$. For Gram-negative bacteria, mean minimum inhibitory and bactericidal concentrations were $3.3 \pm 1.4$ and $6.1 \pm 3.4 \mathrm{mM}$ for SNAC and $12.4 \pm 5.4$ and $26.5 \pm 10.1 \mathrm{mM}$ for GSNO $(P<0.01)$. The minimum bactericidal to inhibitory concentration ratio was $\leq 8$ in $100 \%$ of all isolates tested for SNAC and in $94.2 \%$ tested for GSNO.

Conclusions: SNAC and GSNO had effective inhibitory and bactericidal effects against bacterial isolates from keratitis. SNAC showed greater antimicrobial activity than GSNO against all bacteria. Gram-positive bacteria were more susceptible to the inhibitory and bactericidal effects of the S-nitrosothiols.

Keywords: antimicrobial activity, S-nitroso-N-acetylcysteine, S-nitrosoglutathione, nitric oxide donors, infectious keratitis

\section{Introduction}

Bacterial infectious keratitis is a sight-threatening disease and one of the leading causes of blindness throughout the world. ${ }^{1}$ Due to the large spectrum of possible microorganisms, its treatment requires a combination of topical fortified antibiotics. ${ }^{2}$ Fluoroquinolones, mainly the 8-methoxyfluoroquinolones, gatifloxacin and moxifloxacin, have shown effectiveness as monotherapy. ${ }^{2}$ However, the eminent risk of widespread resistance ${ }^{3,4}$ induced by inappropriate treatment has stimulated a growing interest in new antibacterial strategies.

Nitric oxide (NO) is an endogenous molecule that gained notoriety at the end of the 1980s after the discovery of its effects on smooth muscle relaxation, vasodilatation, and vascular pressure flow control. ${ }^{5}$ In the eye, NO has been shown to be a key
Correspondence: Angelino Julio Cariello Sadalla Amin Ghanem Eye Hospital, I 46 Abdon Batista Street, Joinville, Santa Catatina, Brazil 8920I-010

Tel +55 4734815333

Fax +55 $47348 I 5305$

Email angelino@sadalla.com.br 
regulator of vascular tone in the ophthalmic arteries ${ }^{6}$ involved with increasing blood flow to the retina, choroid, and the optic nerve head. ${ }^{7,8}$ Beyond control of vascular tone, NO was shown to be involved in several bioregulatory systems in the human body, including modulation of the immune response ${ }^{9}$ and toxicity of macrophages toward neoplastic cells ${ }^{10}$ and pathogens. ${ }^{9,11}$ Under physiologic conditions, NO reacts with thiol-containing molecules such as glutathione to form S-nitrosothiols (RSNOs), which are considered to be NO carriers and donors in humans. ${ }^{12}$

The NO-mediated antimicrobial activity of RSNOs has been demonstrated against several pathogens, including protozoa and bacteria. ${ }^{13-15}$ S-nitrosoglutathione (GSNO) and S-nitroso-N-acetylcysteine (SNAC) have also been shown to have potent antimicrobial activity against trophozoites of Acanthamoeba castellanii, the etiological agent responsible for devastating sight-threatening keratitis. ${ }^{16}$ These data suggest that NO donors are important candidates for treating infectious eye diseases.

Although many studies have carried out microbiological tests with bacteria at neutral $\mathrm{pH},{ }^{14,15}$ the bactericidal activity of reactive nitrogen intermediates seems to be remarkable in lower $\mathrm{pH}$ environments. ${ }^{17,18}$ The aim of the present study was to evaluate the antimicrobial activity of two RSNOs, ie, GSNO and SNAC, against clinical bacterial strains isolated from patients with infectious keratitis.

\section{Materials and methods Materials}

Glutathione ( $\gamma$-Glu-Cys-Glu), N-acetyl-cysteine, sodium nitrite $\left(\mathrm{NaNO}_{2}\right)$, hydrochloric acid $(\mathrm{HCl})$, sodium hydroxide $(\mathrm{NaOH})$, phosphate buffer, and acetone were purchased from Sigma (St Louis, MO) and used as received. Cation-adjusted Mueller-Hinton broth (CAMHB) and tryptic soy agar were purchased from Oxoid (Basingstoke, England).

\section{Synthesis of GSNO and SNAC}

GSNO and SNAC were synthesized as previously described. ${ }^{13}$ GSNO was stored at freezer temperature $\left(-20^{\circ} \mathrm{C}\right)$ and protected from light. Freshly prepared stock acidic SNAC solution was diluted in phosphate-buffered saline ( $\mathrm{pH} 7.4$ ) in order to obtain $80.0 \mathrm{mM}$ solutions and was used immediately. Solid GSNO was dissolved in phosphate-buffered solution to obtain $80.0 \mathrm{mM}$ solutions. The final $\mathrm{pH}$ values of both solutions were adjusted to 5.0, 6.0 , and 7.0 by titration with diluted $\mathrm{HCl}$ and $\mathrm{NaOH}$ solutions and measured using a pH meter (Hanna Instruments, Ann Arbor, MI).

\section{Stability of GSNO and SNAC solutions}

Decomposition levels for GSNO and SNAC incubated in $\mathrm{CAMHB}$ at $37^{\circ} \mathrm{C}$ and at pHs 5.0, 6.0, and 7.0 were characterized by monitoring the absorption band of GSNO and SNAC at $336 \mathrm{~nm}$ assigned to the -SNO moiety with a diode-array spectrophotometer (HP-8453, HewlettPackard, Palo Alto, CA) in a $1 \mathrm{~mm}$ optical path cuvette. GSNO and SNAC solutions, previously dissolved in phosphate-buffered saline at $\mathrm{pH} 7.4$, were added to the culture medium to achieve a final concentration of $40.0 \mathrm{mM}$. The $\mathrm{pH}$ of the medium was further adjusted to the desired values by addition of $1 \mathrm{M} \mathrm{NaOH}$ or $\mathrm{HCl}$ solutions. Spectra of the solutions in the culture medium were taken at 2, 3, 5,7 , and 24 hours. The remaining concentrations of the GSNO and SNAC solutions were calculated on the basis of their molar absorption coefficients. This evaluation was performed in duplicate.

\section{Bacterial isolates}

The bacteria used in this study were randomly selected from 222 clinical isolates from patients with infectious keratitis seen at the Department of Ophthalmology of Federal University of São Paulo and enrolled from January to December 2009. Fifty-two (23.4\%) clinical isolates, including 14 (26.9\%) Pseudomonas species, $13(25.0 \%)$ coagulase-negative Staphylococci, 10 (19.2\%) Staphylococcus aureus, nine (17.3\%) Serratia marcescens, and six (11.5\%) Enterobacter aerogenes were recovered twice on blood sheep agar (5\%) from the Ocular Microbiology Laboratory Culture Collection (tryptic soy broth, 15\% glycerol). American Type Culture Collection (ATCC) S. aureus 29213, Staphylococcus epidermidis 12228, Pseudomonas aeruginosa 27853, and E. aerogenes 13048 strains were also included. Harvested colonies (3-5) from fresh and pure cultures were inoculated in $5 \mathrm{~mL}$ of CAMHB and incubated at $37^{\circ} \mathrm{C}$ for $3-4$ hours. The bacterial suspension was adjusted to a $0.5 \mathrm{McF}$ arland standard (about $1.5 \times 10^{8} \mathrm{cfu} / \mathrm{mL}$ ) using a Baxter digital turbidimeter (Sacramento, CA).

\section{Preliminary determination of GSNO and SNAC antibacterial activity against ATCC strains}

In order to investigate the influence of $\mathrm{pH}$ on the antibacterial activity of GSNO and SNAC, four ATCC strains, S. aureus 29213, S. epidermidis 12228, P. aeruginosa 27853 , and $E$. aerogenes 13048 , were tested by broth microdilution using CAMHB with adjusted $\mathrm{pH}$ values of 5.0, 6.0, and 7.0. The minimum inhibitory concentrations (MIC) 
of both compounds were determined by reference broth microdilution, according to the Clinical Laboratory Standard Institute ${ }^{19}$ The final concentrations of GSNO and SNAC tested ranged from $40.0 \mathrm{mM}$ to $0.31 \mathrm{mM}$. The plates were sealed and incubated at $37^{\circ} \mathrm{C}$ for 24 hours. Each experiment was carried out using properly sterile broth controls and controls for bacterial growth in CAMHB without drug. After incubation, the wells were examined and the MIC values (the lowest concentration without visible growth) were assessed.

\section{GSNO and SNAC susceptibility assay against clinical isolates}

Reference broth microdilution assays were performed to determine the MIC of GSNO and SNAC against 52 keratitis isolates as previously described, ${ }^{19}$ using CAMHB adjusted at a final $\mathrm{pH}$ of 5.0 (based on the results of the preliminary test against ATCC strains). The final concentrations of GSNO and SNAC tested ranged from $40.0 \mathrm{mM}$ to $0.31 \mathrm{mM}$. Plates were sealed and incubated for 24 hours at $37^{\circ} \mathrm{C}$ in an aerobic atmosphere. Sterile broth controls and controls for bacterial growth in CAMHB without drug were also included. In addition, glutathione and $\mathrm{N}$-acetyl-cysteine were also incubated with the ATCC strains in order to determine their possible antibacterial activity.

\section{Minimum bactericidal concentration}

Minimum bactericidal concentration (MBC) values were determined for both the ATCC strains (tested at three $\mathrm{pH}$ values) and clinical isolates. The contents of each well showing an inhibitory effect on the broth microdilution assay were assessed for viable bacteria by plating the contents of the wells onto tryptic soy agar plates. A colony count was performed after 24 hours of incubation. After overnight incubation, the bacterial colony was counted to determine the MBC (the lowest concentration showing $\geq 99.9 \%$ killing). Sterility control and bacterial growth control at pH 5.0 were also measured.



Figure I Kinetic curves of GSNO and SNAC decomposition during incubation in cation-adjusted Mueller-Hinton broth ( $\left.37^{\circ} \mathrm{C}\right)$ at $\mathrm{pHs} 5.0,6.0$, and 7.0 over 24 hours in a normalized arbitrary unity scale, based on their absorption bands assigned to the - SNO group.

Notes: Initial concentration: $40 \mathrm{mM}$. Inset: Percentages of GSNO and SNAC remaining after 24 hours at pHs 5.0, 6.0, and 7.0 over 24 hours.

Abbreviations: GSNO, S-nitrosoglutathione; SNAC, S-nitroso-N-acetylcysteine. 


\section{Statistical analysis}

The MIC and MBC values of each genus of bacterium were expressed as the mean \pm standard deviation, MIC and MBC $50 \%$ and $90 \%$, and MBC: MIC ratio. The Kruskal-Wallis test was used to identify differences in the percentage of molecular remnants after 24 hours at the three different $\mathrm{pH}$ levels. Analysis of variance was used to compare the means of MIC and MBC at the three different $\mathrm{pH}$ values, and the TukeyKramer statistical test was used in conjunction with analysis of variance for pairwise comparisons. Comparisons between MIC or MBC for GSNO and SNAC against the clinical isolates were analyzed using the paired-samples $t$-test. $P$ values $<0.05$ were considered statistically significant.

\section{Results}

\section{Stability of GSNO and SNAC}

Figure 1 shows the kinetic curves for GSNO and SNAC decomposition in $\mathrm{CAMHB}$ at $37^{\circ} \mathrm{C}$ and at $\mathrm{pHs} 5.0,6.0$, and 7.0 over 24 hours in a normalized arbitrary unity scale, based on their absorption bands. After 24 hours, variation of $\mathrm{pH}$ in the range 5-7 did not lead to significant changes in the extent of decomposition of either GSNO $(22.9 \% \pm 2.3 \%$, $P=0.964)$ or SNAC $(17.2 \% \pm 2.9 \%, P=0.115)$. The graph bars of the inset show the quantification of the remaining amounts of GSNO and SNAC after their incubation in these conditions for 24 hours.

\section{Influence of $\mathrm{pH}$ on antibacterial activity}

GSNO and SNAC had significantly more antibacterial activity against ATCC strains when tested at pH 5.0 in comparison with pHs 6.0 and $7.0(P<0.05)$. However, there was no difference between the results obtained at $\mathrm{pHs} 6.0$ and $7.0(P>0.05)$. Table 1 shows the MIC and MBC values for GSNO and SNAC against the ATCC strains at the three different $\mathrm{pH}$ levels.

\section{Antibacterial activity of GSNO and SNAC against clinical isolates}

SNAC showed lower MIC and MBC values than GSNO for all the different clinical isolates from patients with infectious keratitis. MIC values for SNAC ranged from $<0.3$ to $5.0 \mathrm{mM}$, with $\mathrm{MIC}_{50}$ and $\mathrm{MIC}_{90}$ values of 2.5 and $5.0 \mathrm{mM}$, respectively, while MIC values for GSNO ranged from $<0.3$ to $20.0 \mathrm{mM}$, with $\mathrm{MIC}_{50}$ and $\mathrm{MIC}_{90}$ values of 10.0 and $20.0 \mathrm{mM}$, respectively. MBC values for SNAC ranged from 1.25 to $20.0 \mathrm{mM}$, with $\mathrm{MBC}_{50}$ and $\mathrm{MBC}_{90}$ values of 5.0 and $10.0 \mathrm{mM}$, respectively, while $\mathrm{MBC}$ values for GSNO ranged from 0.6 to $40.0 \mathrm{mM}$, with $\mathrm{MBC}_{50}$ and $\mathrm{MBC}_{90}$ values of 40.0

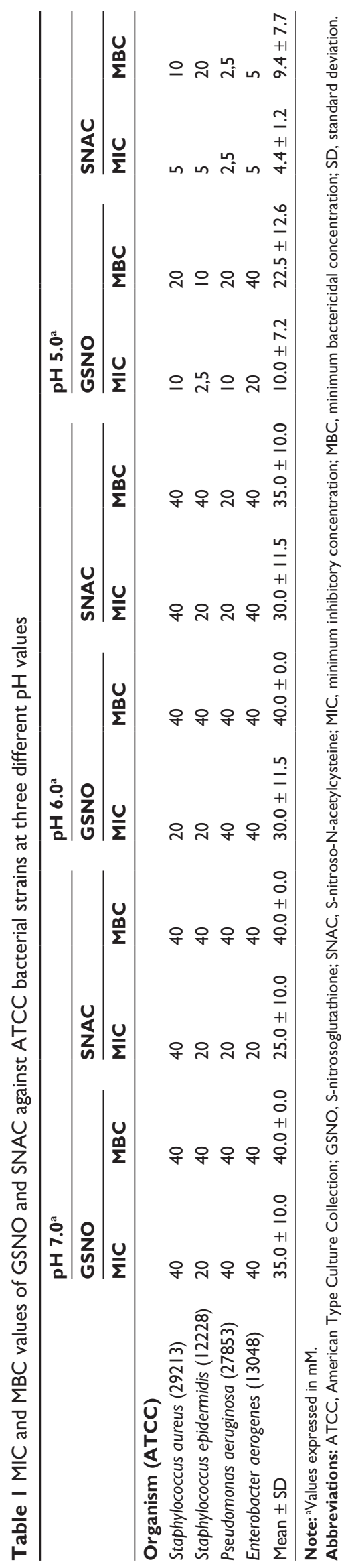


and $40.0 \mathrm{mM}$, respectively. These figures imply mean MIC values of $2.8 \pm 1.5 \mathrm{mM}$ for SNAC and $9.0 \pm 6.0 \mathrm{mM}$ for GSNO $(P<0.01)$, and mean MBC values of $7.2 \pm 3.8 \mathrm{mM}$ for SNAC and $24.3 \pm 11.4 \mathrm{mM}$ for GSNO $(P<0.01$, Tables 2 and 3$)$.

The same higher bactericidal efficacy of SNAC relative to GSNO was observed when analyzing the MIC and MBC values on the basis of Gram staining. For Gram-positive bacteria, the MIC mean values for SNAC and GSNO were $2.1 \pm 1.3$ and $4.6 \pm 3.2 \mathrm{mM}$ and the $\mathrm{MBC}$ mean values were $8.6 \pm 3.8$ and $21.5 \pm 12.5 \mathrm{mM}$, respectively $(P<0.01)$. For Gram-negative bacteria, the mean MIC values of SNAC and GSNO were $3.3 \pm 1.4$ and $12.4 \pm 5.4 \mathrm{mM}$ and the $\mathrm{MBC}$ mean values were $6.1 \pm 3.4$ and $26.5 \pm 10.1 \mathrm{mM}$, respectively $(P<0.01$, Tables 2 and 3$)$.

The overall MBC:MIC ratio was $\leq 8$ in $100 \%$ of all isolates tested for SNAC and $94.2 \%$ for GSNO. The $\mathrm{MBC}$ :MIC ratio for SNAC was $\leq 4$ in $65.2 \%$ and $\leq 8$ in $100 \%$ of Gram-positive isolates and $\leq 4$ in $100 \%$ of Gramnegative isolates. The MBC:MIC ratio for GSNO was $\leq 4$ in $52.2 \%$ and $\leq 8$ in $87 \%$ of Gram-positive isolates and $\leq 4$ in $93.1 \%$ and $\leq 8$ in $100 \%$ of Gram-negative isolates. Only one $S$. aureus isolate showed an MBC:MIC ratio of 32 for GSNO, indicating tolerance.

SNAC also led to lower MIC and MBC values against ATCC $S$. aureus, P. aeruginosa, and E. aerogenes strains at $\mathrm{pH} 5.0$ compared with GSNO. On the other hand, GSNO but not SNAC, displayed lower MIC and $\mathrm{MBC}$ values against the ATCC $S$. epidermidis strain (Table 1). Glutathione and $\mathrm{N}$-acetyl-cysteine did not show any inhibitory or bactericidal effect for any of the ATCC strains tested, demonstrating that the antimicrobial effect observed is mediated by free NO released from the RSNO molecules or by the - SNO moiety of these molecules in their intact forms.
Sterility control wells showed no contamination (all wells showing no visible growth and no colony was examined on the tryptic soy agar plates) and bacterial growth control wells showed adequate growth conditions (all wells showing visible turbidity and full colony formation were examined on the tryptic soy agar plates).

\section{Discussion}

Although numerous studies have documented the bactericidal action of RSNOs against several bacteria responsible for gastrointestinal, ${ }^{14}$ urinary, ${ }^{15}$ and respiratory ${ }^{17,18}$ diseases, each microorganism has a particular pathogenic mechanism and tissue relationship. The present study involving specific causative agents of keratitis confirmed the antimicrobial action of SNAC and GSNO against bacteria responsible for this pathologic condition, indicating that such NO donors might be useful for the topical treatment of ocular infections.

The strict mechanisms of NO-dependent antimicrobial activity are still unclear. Previous studies have demonstrated that NO, a transitory free radical, can directly inhibit bacterial respiratory chain proteins $s^{20,21}$ and disrupt iron-sulfur clusters in bacterial proteins, forming free iron radicals that catalyze toxic oxidative reactions. ${ }^{22,23}$ Iron depletion can also be induced by interaction of NO with metalloenzymes. Moreover, nitrosylation of free thiol groups may result in inactivation of metabolic enzymes. ${ }^{24}$

Reactive nitrogen intermediates can also react with heme groups, phenol, or aromatic amino acid residues, thereby inactivating the actions of proteins. ${ }^{25}$ Additionally, reactive nitrogen intermediates can react with a tyrosyl radical in the ribonucleotide reductase enzyme or with metalloproteins, leading to inhibition of bacterial DNA replication. ${ }^{26,27}$ Deamination, strand breaks, and basic sites are other DNA alterations induced by NO-mediated oxidative damage. ${ }^{28}$

Table 2 MIC and MBC of GSNO and SNAC against different clinical isolates from patients with infectious keratitis

\begin{tabular}{|c|c|c|c|c|c|c|c|}
\hline \multirow[t]{2}{*}{ Organism } & \multirow{2}{*}{$\begin{array}{l}\text { Clinical isolates } \\
\text { n (\%) }\end{array}$} & \multicolumn{2}{|l|}{ MIC (mM) } & \multirow[t]{2}{*}{$P$ value* } & \multicolumn{2}{|l|}{ MBC (mM) } & \multirow[t]{2}{*}{$P$ value* } \\
\hline & & $\begin{array}{l}\text { SNAC } \\
(\text { mean } \pm \text { SD) }\end{array}$ & $\begin{array}{l}\text { GSNO } \\
(\text { mean } \pm \text { SD) }\end{array}$ & & $\begin{array}{l}\text { SNAC } \\
(\text { mean } \pm \text { SD })\end{array}$ & $\begin{array}{l}\text { GSNO } \\
(\text { mean } \pm \text { SD) }\end{array}$ & \\
\hline Gram-positive & $23(44.2 \%)$ & $2.1 \pm 1.3$ & $4.6 \pm 3.2$ & $<0.01$ & $8.6 \pm 3.8$ & $21.5 \pm 12.5$ & $<0.01$ \\
\hline CN Staphylococcus & $13(25.0 \%)$ & $1.9 \pm 1.2$ & $3.2 \pm 1.8$ & $<0.01$ & $9.1 \pm 4.5$ & $15.8 \pm 9.9$ & 0.02 \\
\hline Staphylococcus aureus & $10(19.2 \%)$ & $2.4 \pm 1.5$ & $6.4 \pm 3.9$ & $<0.01$ & $8.0 \pm 2.4$ & $29.0 \pm 11.3$ & $<0.01$ \\
\hline Gram-negative & $29(55.8 \%)$ & $3.3 \pm 1.4$ & $12.4 \pm 5.4$ & $<0.01$ & $6.1 \pm 3.4$ & $26.5 \pm 10.1$ & $<0.01$ \\
\hline Serratia marcescens & $9(17.3)$ & $4.2 \pm 1.2$ & $15.0 \pm 6.1$ & $<0.01$ & $7.8 \pm 5.1$ & $28.9 \pm 10.5$ & $<0.01$ \\
\hline Pseudomonas species & $14(26.9 \%)$ & $2.1 \pm 0.6$ & $8.9 \pm 2.1$ & $<0.01$ & $5.2 \pm 2.3$ & $23.6 \pm 9.3$ & $<0.01$ \\
\hline Enterobacter aerogenes & $6(11.5 \%)$ & $4.6 \pm 1.0$ & $16.8 \pm 5.2$ & $<0.01$ & $5.8 \pm 2.0$ & $30.0 \pm 10.9$ & $<0.01$ \\
\hline Total & $52(100 \%)$ & $2.8 \pm 1.5$ & $9.0 \pm 6.0$ & $<0.01$ & $7.2 \pm 3.8$ & $24.3 \pm 11.4$ & $<0.01$ \\
\hline
\end{tabular}

Note: *Paired-samples t-test.

Abbreviations: CN, coagulase-negative; mM, millimolar; MIC, minimum inhibitory concentration; MBC, minimum bactericidal concentration; GSNO, S-nitrosoglutathione; SNAC, S-nitroso-N-acetylcysteine; SD, standard deviation. 


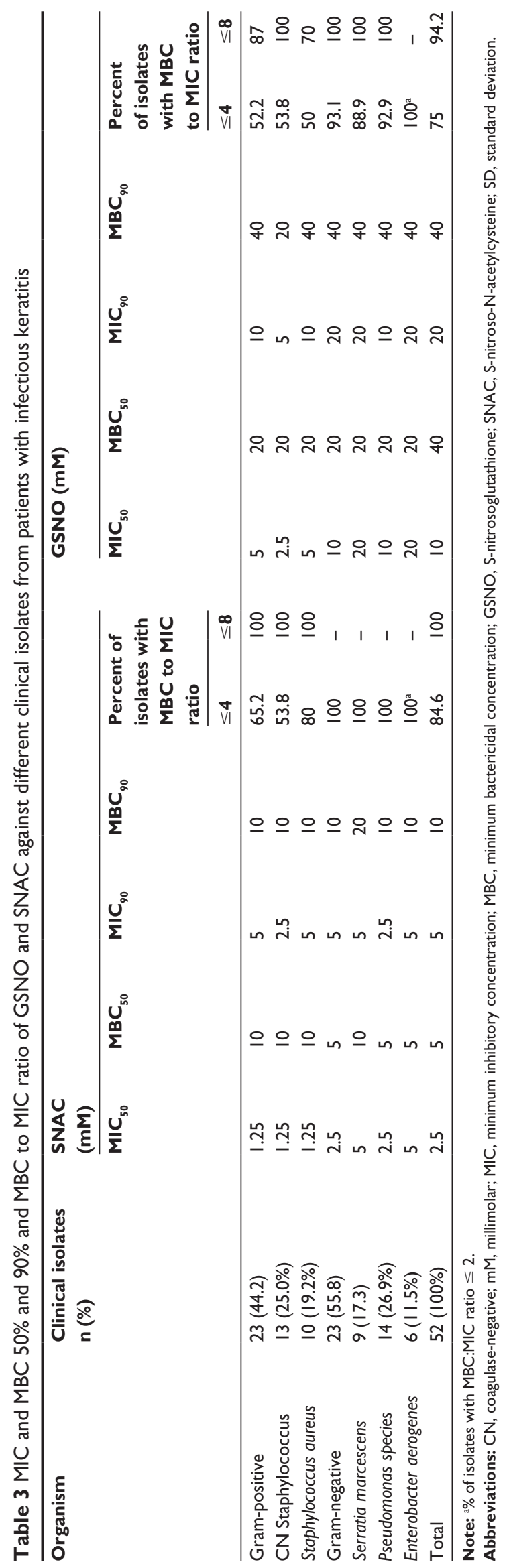

Considering that many targets of NO-mediated antimicrobial actions are intracellular, it is possible that the outer lipopolysaccharide bilayer membrane of Gram-negative bacteria works as a barrier, avoiding the penetration of reactive nitrogen intermediates and protecting them from the inhibitory and bactericidal effect of NO donors in lower concentrations.

In spite of their potential therapeutic applications, the ocular toxicity of RSNOs has not been well characterized yet. Previous studies performed to evaluate the ocular hypotensive effect of other topical NO donors, like sodium nitroprusside and S-nitroso-N-acetylpenicillamine, have reported no adverse effects in the concentration range $1-2 \mathrm{mM} .^{29,30}$ Our laboratory undertook a preliminary study to investigate the ocular toxicity of topical instillation of GSNO and SNAC at concentrations up to $10.0 \mathrm{mM}$ (based initially on results for Acanthamoeba ${ }^{16}$ ), which did not show signs of ocular toxicity in either ex vivo and in vivo assays. ${ }^{31}$ Except for mild and transient conjunctival hyperemia, no other adverse effects were observed. Although the toxic effects in higher concentrations are not known, it is interesting to note that in the present study the inhibitory and bactericidal effect of SNAC against all clinical isolates and the inhibitory effect of GSNO against all Gram-positive and Pseudomonas isolates were obtained in concentations under $10 \mathrm{mM}$.

Previous studies have observed greater bactericidal activity of reactive nitrogen intermediates at $\mathrm{pH} 5.0$ compared with $\mathrm{pH}$ 7.0. ${ }^{17,18}$ Similarly, the present study shows remarkable antibacterial activity of GSNO and SNAC at pH 5.0 in comparison with pHs 6.0 and 7.0. It has been suggested that, in acidic conditions, bactericidal actions due to NO may be associated with its oxidation to nitrite $\left(\mathrm{NO}_{2}^{-}\right)$followed by nitrous acid formation and other reactive nitrogen intermediates. ${ }^{17,18}$ This might be the situation found inside phagosomes of activated macrophages which are supposed to be critical for the antibacterial action of reactive nitrogen intermediates. In order to ensure the bactericidal effect of RSNOs in a possible clinical setting, a weak acid, such as citric or boric acid, could be added into the formulation as a buffer. Since the 1960s, $2 \%$ boric acid (orthoboric acid, $\mathrm{H}_{3} \mathrm{BO}_{3}$ ) solution has been recommended as a general ophthalmic vehicle, with a $\mathrm{pH}$ of about $4.7,{ }^{32}$ and it has been used as a preservative or drug enhancer for various eye drops, including antiglaucomatous and ocular decongestant drugs..$^{33,34}$ Moreover, it has been shown that boric acid has a mild antiseptic action ${ }^{35}$ and can improve the corneal penetration of some ophthalmic agents. ${ }^{36}$

The thermal stability of primary RSNOs is a common concern regarding their clinical application. Measurements of 
spontaneous thermal decomposition of GSNO and SNAC under the same incubation conditions as those used for the control strains at pHs 5.0, 6.0, and 7.0 over 24 hours (Figure 1) showed that both RSNOs undergo decomposition of $22.9 \% \pm 2.7 \%$ (GSNO) and $17.2 \% \pm 1.0 \%$ (SNAC) after 24 hours. Therefore, the remaining concentrations of GSNO and SNAC after 24 hours are still very high and in the millimolar range, what is well above the cytotoxic levels previously observed to kill Leishmania major and Leishmania amazonensis $^{13}\left(\mathrm{IC}_{50}\right.$ in the range 54.6-161 $\left.\mu \mathrm{M}\right)$ and trophozoites of Acanthamoeba castellanii ${ }^{16}(500-1000 \mu \mathrm{M})$ in vitro. Therefore, if the bactericidal actions are due to intact RSNO molecules, we can assume that the incubation media were exposed to high RSNO concentrations over the 24-hour incubation period. On the other hand, free NO release due to $17.2 \%-22.9 \%$ decomposition rate is also a possible factor contributing to the bactericidal action observed. In this sense, a combined action of intact GSNO and SNAC and free NO may operate to promote the observed antimicrobial actions.

In addition to therapeutic topical ocular instillation of GSNO and SNAC, the antimicrobial effect of these compounds could be helpful as a component of contact lens care systems and medical disinfection solutions. However, further studies are necessary to characterize the ocular toxicity, the in vivo effect in infectious keratitis, and the possible mechanisms involved in the bactericidal actions of these RSNOs.

\section{Conclusions}

GSNO and SNAC had bactericidal activity against clinical isolates from patients with infectious keratitis. SNAC showed greater antimicrobial activity than GSNO against all bacteria. Gram-positive bacteria were more susceptible to the inhibitory and bactericidal effects of the S-nitrosothiols.

\section{Disclosure}

GFPS is supported by a studentship from São Paulo Research Foundation (07/55877-3). MGO acknowledges CNPq (Project \#309390/2011-7) for financial support. All other authors report no conflicts of interest in this work.

\section{References}

1. Whitcher JP, Srinivasan M, Upadhyay MP. Corneal blindness: a global perspective. Bull World Health Organ. 2001;79:214-221.

2. Ly CN, Pham JN, Badenoch PR, et al. Bacteria commonly isolated from keratitis specimens retain antibiotic susceptibility to fluoroquinolones and gentamicin plus cephalothin. Clin Exp Ophthalmol. 2006;34:44-50.

3. Kwatra D, Vadlapatla RK, Vadlapudi AD, Pal D, Mitra AK. Interaction of gatifloxacin with efflux transporters: a possible mechanism for drug resistance. Int J Pharm. 2010;395:114-121.
4. Yamada M, Yoshida J, Hatou S, Yoshida T, Minagawa Y. Mutations in the quinolone resistance determining region in Staphylococcus epidermidis recovered from conjunctiva and their association with susceptibility to various fluoroquinolones. Br J Ophthalmol. 2008;92: 848-851.

5. Palmer RMJ, Ferrige AG, Moncada S. Nitric oxide release accounts for the biological activity of endothelium-derived relaxing factor. Nature. 1987;327:524-526.

6. Lockhart CJ, Gamble AJ, Rea D, et al. Nitric oxide modulation of ophthalmic artery blood flow velocity waveform morphology in healthy volunteers. Clin Sci. 2006;111:47-52.

7. Grunwald JE, Iannaccone A, DuPont J. Effect of isosorbide mononitrate on the human optic nerve and choroidal circulations. Br J Ophthalmol. 1999;83:162-167.

8. Schmetterer L, Polak K. Role of nitric oxide in the control of ocular blood flow. Prog Retin Eye Res. 2001;20:823-847.

9. Bogdan C. Nitric oxide and the immune response. Nat Immunol. 2001;2:907-916.

10. Hirst DG, Robson T. Nitrosative stress as a mediator of apoptosis: implications for cancer therapy. Curr Pharm Des. 2010;16:45-55.

11. Fang FC. Antimicrobial reactive oxygen and nitrogen species: concepts and controversies. Nat Rev Microbiol. 2004;2:820-832.

12. Stamler JS, Simon DI, Osborne JA, et al. S-nitrosylation of proteins with nitric oxide: synthesis and characterization of biologically active compounds. Proc Natl Acad Sci U S A. 1992;89:444-448.

13. de Souza GFP, Yokoyama-Yasunaka JKU, Seabra AB, Miguel DC, de Oliveira MG, Uliana SRB. Leishmanicidal activity of primary S-nitrosothiols against Leishmania major and Leishmania amazonensis: Implications for the treatment of cutaneous leishmaniasis. Nitric Oxide. 2006;15:209-216.

14. Abu-Shakra A. The mutagenic activity of the S-nitrosoglutathione/ glutathione system in Salmonella typhimurium TA1535. Mutat Res. 2003;539:203-206.

15. Flatley J, Barrett J, Pullan ST, Hughes MN, Green J, Poole RK. Transcriptional responses of Escherichia coli to S-nitrosoglutathione under defined chemostat conditions reveal major changes in methionine biosynthesis. J Biol Chem. 2005;280:10065-10072.

16. Cariello AJ, de Souza GFP, Foronda AS, Yu MCZ, Höfling-Lima AL, de Oliveira MG. In vitro amoebicidal activity of S-nitrosoglutathione and S-nitroso-N-acetylcysteine against trophozoites of Acanthamoeba castellanii. J Antimicrob Chemother. 2010;65:588-591.

17. Ehrt S, Shiloh MU, Ruan J, et al. A novel antioxidant gene from Mycobacterium tuberculosis. J Exp Med. 1997;186:1885-1896.

18. O’Brien L, Carmichael J, Lowrie DB, Andrew PW. Strains of Mycobacterium tuberculosis differ in susceptibility to reactive nitrogen intermediates in vitro. Infect Immun. 1994;62:5187-5190.

19. Clinical and Laboratory Standards Institute. Methods for dilution antimicrobial susceptibility tests for bacteria that grow aerobically: approved standard M7-A6. Wayne, PA: Clinical and Laboratory Standards Institute; 2003.

20. Pacelli R, Wink DA, Cook JA, et al. Nitric oxide potentiates hydrogen peroxide-induced killing of Escherichia coli. J Exp Med. 1995;182:1469-1479.

21. Stevanin TM, Ioannidis N, Mills CE, Kim SO, Hughes MN, Poole RK. Flavohemoglobin Hmp affords inducible protection for Escherichia coli respiration, catalyzed by cytochromes bo' or bd, from nitric oxide. J Biol Chem. 2000;275:35868-35875.

22. Flint DH, Tuminello JF, Emptage MHJ. The inactivation of Fe-S cluster containing hydro-lyases by superoxide. Biol Chem. 1993;268:22369-22376.

23. Keyer K, Imlay JA. Superoxide accelerates DNA damage by elevating free-iron levels. Proc Natl Acad Sci U S A. 1996;93:13635-13640.

24. Fang FC. Perspectives series: host/pathogen interactions. Mechanisms of nitric oxide-related antimicrobial activity. J Clin Invest. 1997;99:2818-2825.

25. Ischiropoulos $\mathrm{H}$, al-Mehdi AB. Peroxynitrite-mediated oxidative protein modifications. FEBS Lett. 1995;364:279-282. 
26. Schapiro JM, Libby SJ, Fang FC. Inhibition of bacterial DNA replication by zinc mobilization during nitrosative stress. Proc Natl Acad Sci US A. 2003;100:8496-8501.

27. Lepoivre M, Fieschi F, Coves J, Thelander L, Fontecave M. Inactivation of ribonucleotide reductase by nitric oxide. Biochem Biophys Res Commun. 1991;179:442-448.

28. Juedes MJ, Wogan GN. Peroxynitrite-induced mutation spectra of pSP189 following replication in bacteria and in human cells. Mutat Res. 1996;349:51-61.

29. Behar-Cohen FF, Goureau O, D'Hermies F, Courtois Y. Decreased intraocular pressure induced by nitric oxide donors is correlated to nitrite production in the rabbit eye. Invest Ophthalmol Vis Sci. 1996;37: 1711-1715.

30. Carreiro S, Anderson S, Gukasyan HJ, Krauss A, Prasanna G. Correlation of in vitro and in vivo kinetics of nitric oxide donors in ocular tissues. J Ocul Pharmacol Ther. 2009;25:105-112.

31. Cariello AJ, Souza GFP, Lowen MS, Nakayama SA, Oliveira MG, Höfling-Lima AL. Assessment of in vivo ocular toxicity of nitric oxide donors compounds. Proceedings of ARVO Annual Meeting, Fort Lauderdale, FL, May 2-6, 2010. Invest Ophthalmol Vis Sci. 2010;51: Abstract 3123.
32. Brown MRW, Norton DA. The preservation of ophthalmic preparations. J Soc Cosmet Chem. 1965;16:369-393.

33. Nagai N, Murao T, Okamoto N, Ito Y. Comparison of corneal wound healing rates after instillation of commercially available latanoprost and travoprost in rat debrided corneal epithelium. J Oleo Sci. 2010;59: 135-141.

34. Roldán-Pallarés M, Avila MI, Refojo MF. The use of boric acid solution to help in the removal of biodegraded Miragel episcleral buckles. Retina. 2005;25:90-93.

35. Houlsby RD, Ghajar M, Chaves G. Microbiologic characteristics of unpreserved saline. J Am Optom Assoc. 1998;59:184-188.

36. Kikuchi T, Suzuki M, Kusai A, Iseki K, Sasaki H. Synergistic effect of EDTA and boric acid on corneal penetration of CS-088. Int J Pharm. 2005;290:83-89.
Clinical Ophthalmology

\section{Publish your work in this journal}

Clinical Ophthalmology is an international, peer-reviewed journal covering all subspecialties within ophthalmology. Key topics include: Optometry; Visual science; Pharmacology and drug therapy in eye diseases; Basic Sciences; Primary and Secondary eye care; Patient Safety and Quality of Care Improvements. This journal is indexed on

\footnotetext{
Submit your manuscript here: http://www.dovepress.com/clinical-ophthalmology-journal
}

\section{Dovepress}

PubMed Central and CAS, and is the official journal of The Society of Clinical Ophthalmology (SCO). The manuscript management system is completely online and includes a very quick and fair peer-review system, which is all easy to use. Visit http://www.dovepress.com/ testimonials.php to read real quotes from published authors. 